\title{
Dryland Winter Wheat Yield, Grain Protein, and Soil Nitrogen Responses to Fertilizer and Biosolids Applications
}

\author{
Richard T. Koenig, ${ }^{1}$ Craig G. Cogger, ${ }^{2}$ and Andy I. Bary ${ }^{2}$ \\ ${ }^{1}$ Department of Crop and Soil Sciences, Washington State University, Pullman, WA 99164-6420, USA \\ ${ }^{2}$ Department of Crop and Soil Sciences and Puyallup Research and Extension Center, Washington State University, \\ 2606 West Pioneer Way, Puyallup, WA 98371, USA
}

Correspondence should be addressed to Richard T. Koenig, richk@wsu.edu

Received 15 December 2010; Revised 19 February 2011; Accepted 23 February 2011

Academic Editor: Rodrigo Studart Corrêa

Copyright ( $) 2011$ Richard T. Koenig et al. This is an open access article distributed under the Creative Commons Attribution License, which permits unrestricted use, distribution, and reproduction in any medium, provided the original work is properly cited.

Applications of biosolids were compared to inorganic nitrogen $(\mathrm{N})$ fertilizer for two years at three locations in eastern Washington State, USA, with diverse rainfall and soft white, hard red, and hard white winter wheat (Triticum aestivum L.) cultivars. High rates of inorganic $\mathrm{N}$ tended to reduce yields, while grain protein responses to $\mathrm{N}$ rate were positive and linear for all wheat market classes. Biosolids produced 0 to $1400 \mathrm{~kg} \mathrm{ha}^{-1}$ (0 to $47 \%$ ) higher grain yields than inorganic $\mathrm{N}$. Wheat may have responded positively to nutrients other than $\mathrm{N}$ in the biosolids or to a metered $\mathrm{N}$ supply that limited vegetative growth and the potential for moisture stress-induced reductions in grain yield in these dryland production systems. Grain protein content with biosolids was either equal to or below grain protein with inorganic $\mathrm{N}$, likely due to dilution of grain $\mathrm{N}$ from the higher yields achieved with biosolids. Results indicate the potential to improve dryland winter wheat yields with biosolids compared to inorganic $\mathrm{N}$ alone, but perhaps not to increase grain protein concentration of hard wheat when biosolids are applied immediately before planting.

\section{Introduction}

Biosolids are an effective and relatively safe source of nitrogen $(\mathrm{N})$ for dryland wheat production [1-3]. Applied at agronomic rates, biosolids can supply sufficient $\mathrm{N}$ to maximize yield, as well as a host of other nutrients that can benefit crops in a rotational sequence $[4,5]$. Determining appropriate agronomic application rates is paramount in balancing nutrient (mainly $\mathrm{N}$ ) needs of wheat without increasing the risk of nitrate $\left(\mathrm{NO}_{3}^{-}\right)$leaching. Considerable research has been devoted to this subject $[3,5]$.

In the inland Pacific Northwest (PNW) USA, soft white winter wheat is the predominant crop grown on over 2.75 million ha of mainly dryland (rainfed) cropland [6]. The majority of this wheat is exported and used to make unleavened products such as flat breads, noodles, and cakes [7]. Low-grain protein concentration $(<10 \%)$ is desirable when producing unleavened products. High-grain protein concentration in soft white winter wheat has been a problem in the PNW due, in part, to high soil N levels [7]. Previous biosolids research in this area has shown that agronomic applications at or above rates required to maximize yield may produce undesirably high grain protein concentrations in soft white winter wheat $[3,5]$. While high grain protein concentration is detrimental for soft wheat end uses, high protein is desirable in hard red and white winter wheats, with optimum targets of approximately 11.5 and $12.5 \%$, respectively. Biosolids may be more appropriately suited to hard wheat production in dryland areas of the PNW, as is the case in the state of Colorado, USA [8].

The objective of this study was to determine if biosolids applied at agronomic rates are a more suitable source of $\mathrm{N}$ for producing dryland hard red and white wheat grain with a higher and more desirable protein concentration than soft white wheat grain.

\section{Materials and Methods}

Field studies were conducted at three locations in fall 2006 and again in separate but nearby $(<200 \mathrm{~m}$ distant $)$ 
TABLE 1: Crop year precipitation and preplant soil test information for each site-year. Plant-available soil moisture is calculated by the commercial testing lab from gravimetric moisture content, an assumed bulk density of $1.2 \mathrm{~g} \mathrm{~cm}^{-3}$ for silt loam soil textures, and an assumed permanent wilting point moisture content of $11 \%$ by volume.

\begin{tabular}{|c|c|c|c|c|c|c|c|c|c|}
\hline Location $^{\dagger}$ & Year & $\begin{array}{c}\text { Sept } 1 \text { to Aug } 31 \text { crop } \\
\text { year precipitation } \\
(\mathrm{mm})\end{array}$ & $\begin{array}{c}\text { Plant-available } \\
\text { moisture } \\
\left(\mathrm{cm} 1.5-\mathrm{m}^{-1}\right)\end{array}$ & $\begin{array}{l}\text { Residual } \\
\quad \mathrm{N} \\
\left(\mathrm{kg} \mathrm{ha}^{-1}\right)\end{array}$ & $\begin{array}{c}\text { Organic } \\
\text { matter } \\
\left(\mathrm{g} \mathrm{kg}^{-1}\right)\end{array}$ & $\mathrm{pH}$ & $\begin{array}{c}\mathrm{NaHCO}_{3}^{-} \\
\text {extractable } \mathrm{P}^{\ddagger} \\
\left(\mathrm{mg} \mathrm{kg}^{-1}\right)\end{array}$ & $\begin{array}{c}\mathrm{NaHCO}_{3}^{-} \\
\text {extractable K } \\
\left(\mathrm{mg} \mathrm{kg}^{-1}\right)\end{array}$ & $\begin{array}{c}\text { Water- } \\
\text { extractable } \mathrm{SO}_{4} \S \\
\left(\mathrm{kg} \mathrm{Sha}^{-1}\right)\end{array}$ \\
\hline \multirow{2}{*}{ Lind } & 2006 & 304 & $5.5(0.3)$ & $141(22)^{\Re}$ & $8(1.0)$ & $7.5(0.1)$ & $6(0.6)$ & $524(31)$ & $16(3.2)$ \\
\hline & 2007 & 229 & $2.5(0.4)$ & $189(17)$ & $11(0.7)$ & $6.8(0.1)$ & $17(3.2)$ & $469(10)$ & $12(1.5)$ \\
\hline \multirow{2}{*}{ Davenport } & 2006 & 336 & $8.5(0.7)$ & $156(41)$ & $31(3.2)$ & $6.7(0.5)$ & $12(0.6)$ & 437 (49) & $9(0.6)$ \\
\hline & 2007 & 196 & 8.5 & 113 & 24 & 5.6 & 20 & 416 & 7 \\
\hline \multirow{2}{*}{ Pullman } & 2006 & 452 & 3.9 & 70 & 23 & 5.5 & 28 & 281 & 11 \\
\hline & 2007 & 510 & 6.4 & 76 & 30 & 5.8 & 26 & 266 & 8 \\
\hline
\end{tabular}

${ }^{\dagger}$ Soil series and taxonomic names.

Lind: Shano silt loam — coarse-silty, mixed, mesic, superactive Xeric Haplocambid (both years).

Davenport: Mondovi silt loam—coarse-silty, mixed, mesic, superactive Cumulic Haploxeroll (2006-07).

Hanning silt loam-fine-silty, mixed, mesic, superactive Pachic Argixeroll (2007-08).

Pullman: Palouse silt loam-fine-silty, mixed, superactive Pachic Ultic Haploxeroll (both years).

${ }^{\ddagger}$ Critical values for sufficient soil test $\mathrm{P}$ (bicarbonate method) are $>16 \mathrm{mg} \mathrm{kg}^{-1}$ [9].

$\S$ Critical values for sufficient soil test $\mathrm{S}$ are $>22$ to $34 \mathrm{~kg} \mathrm{ha}^{-1}$ [9].

"Mean (standard deviation) of three replicate samples. If no standard deviation is indicated then only one, 5-point composite was collected from the study area.

locations in fall 2007. The locations were selected to represent three common but contrasting rainfed wheat production systems in eastern Washington State characterized by a Mediterranean climate and precipitation gradient of $<300$ to $>600 \mathrm{~mm}$ year $^{-1}$. The Lind site $\left(46^{\circ} 58.3^{\prime} \mathrm{N}, 118^{\circ} 36.9^{\prime} \mathrm{W}\right)$ typically receives 200 to $250 \mathrm{~mm}$ precipitation year $^{-1}$ and is in a two-year, winter wheat-tillage fallow rotation. The Davenport site $\left(47^{\circ} 39.2^{\prime} \mathrm{N}, 118^{\circ} 9^{\prime} \mathrm{W}\right)$ typically receives 250 to $350 \mathrm{~mm}$ precipitation year $^{-1}$ and is in a threeyear, winter wheat-spring wheat-chemical fallow (no-tillage)

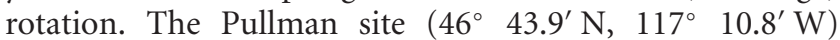
typically receives 500 to $600 \mathrm{~mm}$ precipitation year ${ }^{-1}$ and is in a three-year, winter wheat-spring wheat-spring legume no-till rotation. Actual precipitation totals received at each site during this study are presented in Table 1. Each site was farmed uniformly for $>2$ years prior to these studies.

At each location, preplant soil samples were collected in $0.3-\mathrm{m}$ increments to a depth of $1.5 \mathrm{~m}$ to quantify plantavailable soil moisture and residual $\mathrm{N}$, as well as other soil properties, prior to establishing each study (Table 1). Inorganic $\mathrm{N}$ fertilizer was applied at rates intended to supply 0 to 150 or $200 \%$ of the standard agronomic recommendation [9] based on forecast yield potential and the initial soil test $\mathrm{N}$ at each location. Actual rates of application ranged from 0 to $112 \mathrm{~kg} \mathrm{Nha}^{-1}$ except at Pullman 2007-08, where rates ranged from 0 to $180 \mathrm{~kg} \mathrm{Nha}^{-1}$. The $\mathrm{N}$ source used was dry urea $(46 \% \mathrm{~N})$.

Biosolids sources included Class A dewatered cake (22\% solids) from Tacoma, Wash, produced by thermophilicmesophilic digestion, and Soundgro, Class A heat-dried (93\% solids) biosolids from Pierce County, Wash. Biosolids rates were calculated to supply approximately $1 \times$ and $2 \times$ of the agronomic rate of $\mathrm{N}$ for these scenarios. Data points for biosolids treatments are graphed on inorganic $\mathrm{N}$ response functions (Figures 1 and 2) at the mid and high $\mathrm{N}$ rates for each site-year. Biosolids rates and equivalent plant-available $\mathrm{N}$ supply are presented in Table 2. Based on previous research on $\mathrm{N}$ availability from dewatered and heat-dried biosolids [10] we estimated plant-available $\mathrm{N}$ of both biosolids sources as $25 \%$ of total $\mathrm{N}$ under the conditions of this study and used that estimate for our field application rates (Table 2). In a more recent study of heat-dried biosolids conducted in western Washington State in 2007-2009, Cogger et al. [11] reported much greater $\mathrm{N}$ availability from Soundgro, and we adjusted our estimate of available $\mathrm{N}$ applied from Soundgro to $50 \%$ of total $\mathrm{N}$. The ramifications of this change are discussed later. Biosolids were surface applied at or up to two weeks prior to planting at each location. Biosolids were not incorporated. Inorganic $\mathrm{N}$ was applied two weeks prior to planting at the Lind location and immediately prior to planting at Davenport and Pullman by banding the $\mathrm{N} 20$ to $25 \mathrm{~cm}$ below the surface. At Davenport and Pullman, an ammonium phosphate-sulfate starter fertilizer was applied with the seed at rates of $9 \mathrm{~kg} \mathrm{~N}, 5 \mathrm{kgP}$, and $13 \mathrm{~kg} \mathrm{Sha}^{-1}$.

Three market classes of winter wheat (soft white, hard white, hard red) were planted at each location. For soft white, cv. "Eltan" was planted at Lind and Davenport and "Madsen" planted at Pullman in 2006. The same cultivars were planted in 2007 but Madsen was used at both Davenport and Pullman. The hard red cv. "Bauermeister" was planted at Lind, and "Paladin" was planted at Davenport and Pullman for both years of the study. The hard white cv. "MDM" was planted at all three sites and for both years. Seeding rates were $50 \mathrm{~kg} \mathrm{ha}^{-1}$ at Lind and $90 \mathrm{~kg} \mathrm{ha}^{-1}$ at Davenport and Pullman. Row spacing was $19 \mathrm{~cm}$ at Davenport and Pullman and $40 \mathrm{~cm}$ at Lind. 

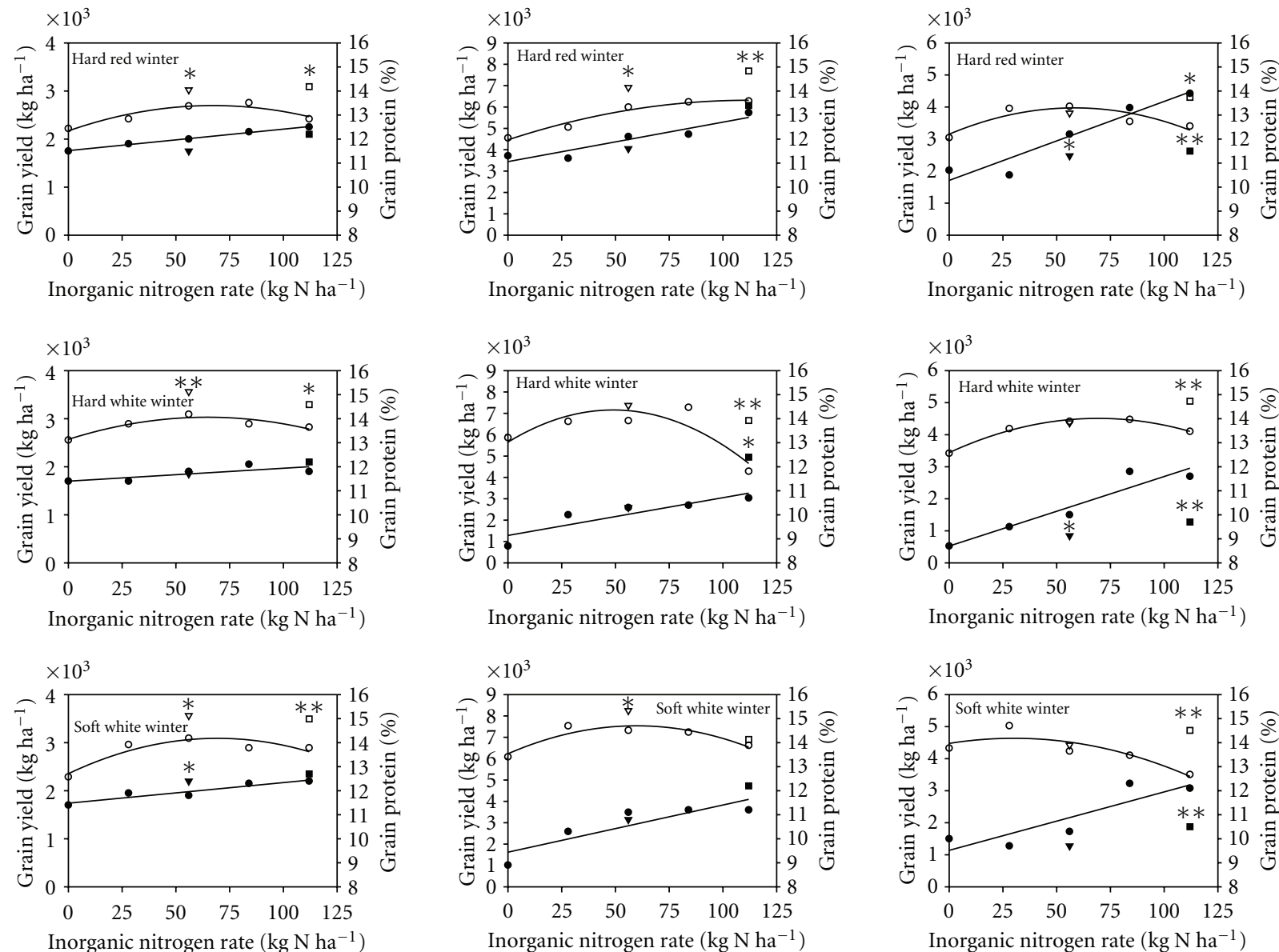

- Inorganic $\mathrm{N}$ yield

$\checkmark$ Biosolids $1 \mathrm{x}$ rate yield

- Biosolids 2x rate yield

- Inorganic $\mathrm{N}$ protein

- Biosolids 1x rate protein

- Biosolids 2x rate protein

(a)

- Inorganic $\mathrm{N}$ yield

$\checkmark$ Biosolids $1 \mathrm{x}$ rate yield

- Biosolids 2x rate yield

- Inorganic $\mathrm{N}$ protein

- Biosolids 1x rate protein

- Biosolids 2x rate protein

(b)
- Inorganic N yield

$\checkmark$ Biosolids $1 \mathrm{x}$ rate yield

- Biosolids $2 \mathrm{x}$ rate yield

- Inorganic $\mathrm{N}$ protein

- Biosolids $1 \mathrm{x}$ rate protein

- Biosolids 2x rate protein

(c)

Figure 1: The effect of inorganic $\mathrm{N}$ fertilizer and biosolids on yield and grain protein content of three wheat market classes at Lind (a), Davenport (b), and Pullman (c), Wash in 2007. The horizontal axis ( $\mathrm{N}$ rate) is the same for each graph panel. Due to large differences in grain yield, the vertical axis changes for each market class site (column). Where indicated by the regression line, quadratic or linear responses are significant at $P<.05$. $^{*}$ and $* *$ indicate significant differences at the 0.10 and 0.05 level, respectively, between inorganic $\mathrm{N}$ and biosolids treatments at that inorganic nitrogen and biosolids rate.

Individual plot dimensions were 2.1 (Davenport and Pullman) or 2.5 (Lind) $\mathrm{m}$ wide by $15.4 \mathrm{~m}$ long. A $1.5 \mathrm{~m}$ wide by $12.3 \mathrm{~m}$ long $\left(18.5 \mathrm{~m}^{2}\right)$ area was harvested with a small combine from the center of each plot at physiological maturity. Grain density (test weight) was measured using standard procedures. Grain protein content was measured using near infrared spectroscopy. Postharvest soil samples were collected in the 0 , mid, and high fertilizer $\mathrm{N}$ rate treatments as well as the $1 \times$ and $2 \times$ biosolids treatments of the hard red winter wheat market class only. A composite sample of three cores was collected from each plot in 0.3$\mathrm{m}$ increments to a depth of $1.5 \mathrm{~m}$. Postharvest soil samples were analyzed for residual nitrate (0 to $1.5 \mathrm{~m}$ depth) and ammonium (surface $0.3 \mathrm{~m}$ only).
2.1. Statistics. Wheat market class was treated as the main plot and fertility treatment the subplot in a randomized complete block, split-plot design with three replications at each location. There were significant site by year and site by $\mathrm{N}$ rate interactions within years. Therefore, data were analyzed and presented separately by site and year. Yield and grain protein responses to fertilizer $\mathrm{N}$ rate were evaluated using first (linear) and second (quadratic) order polynomial models (Figures 1 and 2). Biosolids at $1 \times$ and $2 \times$ rates were compared at the intermediate and high inorganic $\mathrm{N}$ rates, respectively, using ANOVA. Postharvest residual soil N was analyzed using ANOVA with soil depth and treatment variables. Least significant difference (LSD) values at the 5\% level were calculated and presented graphically as bars on 

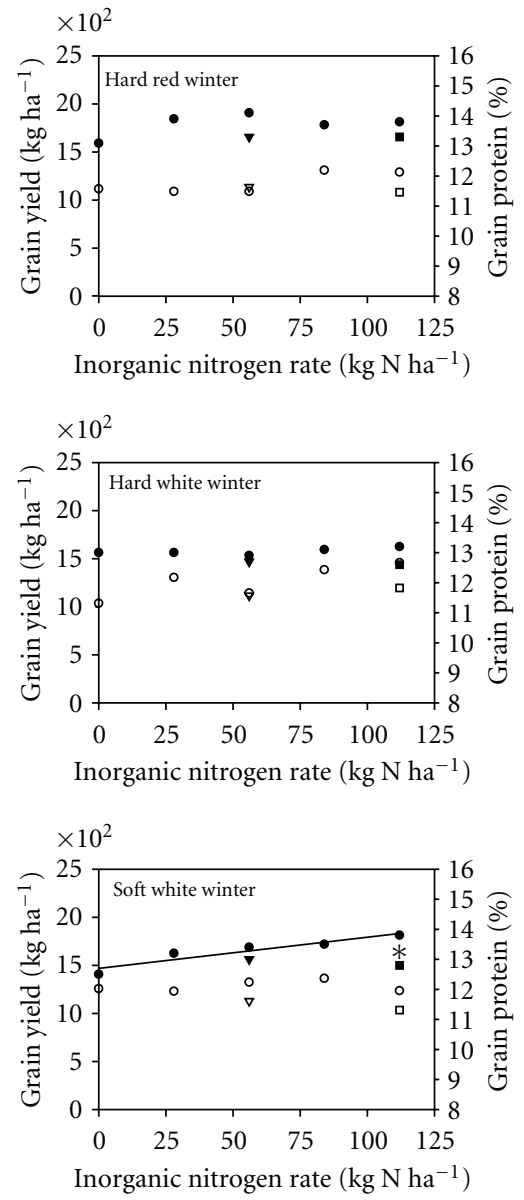

- Inorganic $\mathrm{N}$ yield

$\checkmark$ Biosolids 1x rate yield

- Biosolids $2 \mathrm{x}$ rate yield

- Inorganic $\mathrm{N}$ protein

- Biosolids 1x rate protein

- Biosolids 2x rate protein

(a)
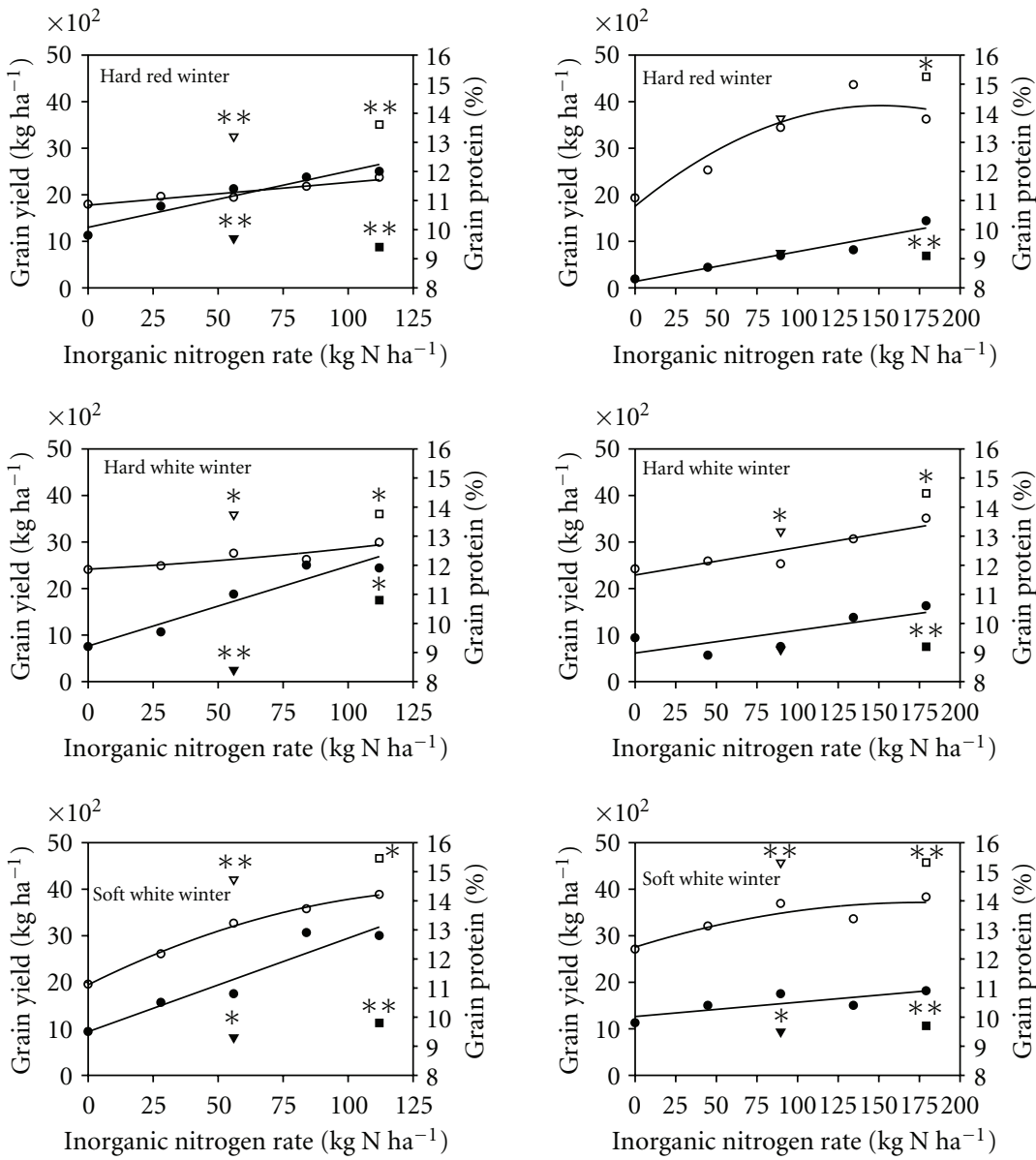

- Inorganic $\mathrm{N}$ yield

$\checkmark$ Biosolids 1x rate yield

- Biosolids 2x rate yield

- Inorganic $\mathrm{N}$ protein

- Biosolids 1x rate protein

- Biosolids 2x rate protein

(b)
- Inorganic $\mathrm{N}$ yield

$\nabla$ Biosolids 1x rate yield

- Biosolids 2x rate yield

- Inorganic N protein

- Biosolids 1x rate protein

- Biosolids 2x rate protein

(c)

FIgure 2: The effect of inorganic $\mathrm{N}$ fertilizer and biosolids on yield and grain protein content of three wheat market classes at Lind (a), Davenport (b), and Pullman (c), Wash in 2008. The horizontal axis ( $\mathrm{N}$ rate) is the same for Lind and Davenport but higher for Pullman. Due to differences in grain yield, the vertical axis is different for Lind relative to Davenport and Pullman. Where indicated by the regression line, quadratic or linear responses are significant at $P<.05$. If no regression line is included the relationship was not significant $(P>.05)$. ${ }^{*}$ and ${ }^{* *}$ indicate significant differences at the 0.10 and 0.05 level, respectively, between inorganic $\mathrm{N}$ and biosolids treatments at that inorganic nitrogen and biosolids rate.

the soil profile $\mathrm{N}$ graphs (Figure 3). Treatment effects on the soil inorganic $\mathrm{N}$ balance were separated using Tukey's Honest Significant Difference at $\alpha=0.05$ (Figure 4).

\section{Results and Discussion}

3.1. Precipitation and Initial Soil Properties at Each Location. Precipitation was near the long-term averages for each location during the 2006-2007 and 2007-2008 crop years (Table 1). Residual plant-available soil moisture generally reflected previous management and precipitation received at each site, where a year of fallow preceding the crop year (Lind and Davenport) was reflected in soil profile moisture measured prior to planting. There was significant residual $\mathrm{N}$ at the Lind and Davenport sites. This is largely due to local practice and cropping history, where soil testing is rarely undertaken in low rainfall/low yielding sites like Lind, and a year of fallow preceding the winter wheat crop permits additional organic $\mathrm{N}$ mineralization leading to higher preplant residual $\mathrm{N}$ levels. Soil test phosphorus (P) was below the recommended critical value for two of the site-years (Lind and Davenport 2006-2007) and near the critical value for Lind 2007-2008. Again, this is a reflection 
TABle 2: Biosolids total N, ammonium $\left(\mathrm{NH}_{4}\right)-\mathrm{N}$, solids content and material, and $\mathrm{N}$ application rates for each site-year. Soundgro and Tacoma are two biosolids products produced in the Seattle, Washington metropolitan area.

\begin{tabular}{|c|c|c|c|c|c|c|c|c|c|c|}
\hline Year & Site & $\begin{array}{c}\text { Biosolids } \\
\text { origin }\end{array}$ & $\begin{array}{c}\text { Total N } \\
\%\end{array}$ & $\begin{array}{c}\mathrm{NH}_{4}-\mathrm{N} \\
\%\end{array}$ & $\begin{array}{c}\text { Solids } \\
\text { \% }\end{array}$ & $\begin{array}{l}\text { Rate } \\
\text { code }\end{array}$ & $\begin{array}{c}\text { Dry application } \\
\text { rate } \\
\mathrm{Mg} \mathrm{ha}^{-1}\end{array}$ & $\begin{array}{l}\text { Total N } \\
\mathrm{kg} \mathrm{ha}^{-1}\end{array}$ & $\begin{array}{c}\text { Estimated } \\
\text { available } \mathrm{N}^{\dagger} \\
\% \text { of total } \mathrm{N}\end{array}$ & $\begin{array}{c}\text { Plant-available } \\
\mathrm{N} \\
\mathrm{Kg} \mathrm{ha}^{-1}\end{array}$ \\
\hline \multirow{6}{*}{2006} & Lind & Soundgro & 5.80 & 0.53 & 93.3 & $1 \times$ & 4.4 & 257 & 50 & 129 \\
\hline & & & 5.80 & 0.53 & 93.3 & $2 \times$ & 8.8 & 508 & 50 & 254 \\
\hline & Davenport & Soundgro & 5.85 & 0.56 & 91.6 & $1 \times$ & 5.4 & 314 & 50 & 157 \\
\hline & & & 5.85 & 0.56 & 91.6 & $2 \times$ & 10.9 & 635 & 50 & 317 \\
\hline & Pullman & Tacoma & 4.60 & 0.78 & 21.5 & $1 \times$ & 6.4 & 295 & 25 & 74 \\
\hline & & & 4.60 & 0.78 & 21.5 & $2 \times$ & 12.9 & 591 & 25 & 148 \\
\hline \multirow{6}{*}{2007} & Lind & Tacoma & 4.90 & 0.40 & 22.5 & $1 \times$ & 5.0 & 247 & 25 & 62 \\
\hline & & & 4.90 & 0.40 & 22.5 & $2 \times$ & 10.1 & 494 & 25 & 123 \\
\hline & Wilke & Soundgro & 6.10 & 0.29 & 93.6 & $1 \times$ & 5.5 & 334 & 50 & 167 \\
\hline & & & 6.10 & 0.29 & 93.6 & $2 \times$ & 11.1 & 676 & 50 & 338 \\
\hline & Pullman & Soundgro & 6.10 & 0.29 & 93.6 & $1 \times$ & 6.5 & 398 & 50 & 199 \\
\hline & & & 6.10 & 0.29 & 93.6 & $2 \times$ & 13.0 & 796 & 50 & 398 \\
\hline
\end{tabular}

${ }^{\dagger}$ Available N estimate is $25 \%$ total $\mathrm{N}$ for Tacoma product and $50 \%$ total $\mathrm{N}$ for Soundgro based on Sullivan et al. [3] and Cogger et al. [11].

of local practice where, due to low yields, farmers rarely use $\mathrm{P}$ fertilizer in the Lind area and only occasionally use $\mathrm{P}$ at Davenport, relative to Pullman. Soil test sulfur (S) was below critical values at all site-years.

3.2. Wheat Response to Inorganic N Fertilizer and Biosolids. Grain yield responses to inorganic $\mathrm{N}$ were exclusively quadratic in 2007 (Figure 1) and quadratic for three of the nine site $\times$ market class datasets in 2008 (Figure 2). At Davenport, the high $\mathrm{N}$ rate-induced depression of grain yields in 2007 was associated with wheat lodging. Lodging was not a problem at Lind or Pullman in 2007. In 2008, grain test weight at these locations (data not presented) tended to be lower at high $\mathrm{N}$ rates indicating stress caused, perhaps, by moisture depletion. In 2008, grain yield did not respond to inorganic $\mathrm{N}$ at Lind (Figure 2). Moisture limitation at Lind, as evidenced by the low 2007-2008 crop year precipitation and preplant residual soil moisture (Table 1), coupled with the relatively high residual $\mathrm{N}$ in this year, apparently limited yield responses to N. Precipitation and preplant soil moisture at Pullman were higher during the 2007-08 crop year and would explain the lack of negative response to high $\mathrm{N}$ rate at this location.

Quadratic responses to inorganic $\mathrm{N}$ fertilizer are common in dryland wheat fertility experiments conducted in this Mediterranean environment $[3,12]$, but not as dramatic in environments where more rainfall occurs during the summer growing season and biosolids were used as the nutrient source $[8,13]$. Negative yield responses to $\mathrm{N}$ have been documented in Australia and are generally referred to as "haying off" [14]. The explanation of this phenomenon is that high levels of available $\mathrm{N}$ induce a flush of vegetative growth that depletes moisture early in the growing season. This leads to a postanthesis water deficit and severely restricts the translocation of pre-anthesis carbon to the grain, as well as postanthesis assimilation of new carbon destined for wheat kernels.

Grain protein concentration increased linearly with fertilizer N rate for all market classes and locations in 2007 (Figure 1) and at the Davenport and Pullman locations in 2008 (Figure 2). A linear response of grain protein concentration to $\mathrm{N}$ rate is common in $\mathrm{N}$ response studies of cereals [12], even when yield plateaus or is negatively impacted by high $\mathrm{N}$ rates [15]. Soft white winter wheat grain proteins were higher than desired across all $\mathrm{N}$ rates at Lind. For hard red and white market classes, yield and grain protein concentration response to fertilizer $\mathrm{N}$ suggest fertilizing at rates above maximum yield, and consequently reducing grain yield, may be required to achieve target protein concentrations for each market class. This is likely an issue of timing of fertilization and positional availability of $\mathrm{N}$ since previous research has shown that plant-available $\mathrm{N}$ residing deep in the profile is more effective than shallow or recently applied $\mathrm{N}$ at contributing to high grain protein concentration in dryland wheat $[16,17]$.

In both 2007 and 2008, grain yields were frequently higher for biosolids than for inorganic $\mathrm{N}$ treatments (Figures 1 and 2). Across site-years, yields with biosolids were 0 to $47 \%$ higher than the highest yields achieved with inorganic fertilizer. At the site with the largest differential between fertility sources (2007 Davenport hard red), biosolids produced $1400 \mathrm{~kg} \mathrm{ha}^{-1}(>20 \%)$ higher grain yield than the highest fertilizer $\mathrm{N}$ yield. In no situation did biosolids result in significantly lower grain yields than an inorganic $\mathrm{N}$ treatment.

Initial attempts to target biosolids agronomic rates to match the intermediate ( 56 or $90 \mathrm{~kg} \mathrm{~N} \mathrm{ha}^{-1}$ ) or high (112 or $180 \mathrm{~kg} \mathrm{~N} \mathrm{ha}^{-1}$ ) $\mathrm{N}$ fertilizer rates were apparently unsuccessful based on $\mathrm{N}$ availability calculations as a fraction of total 


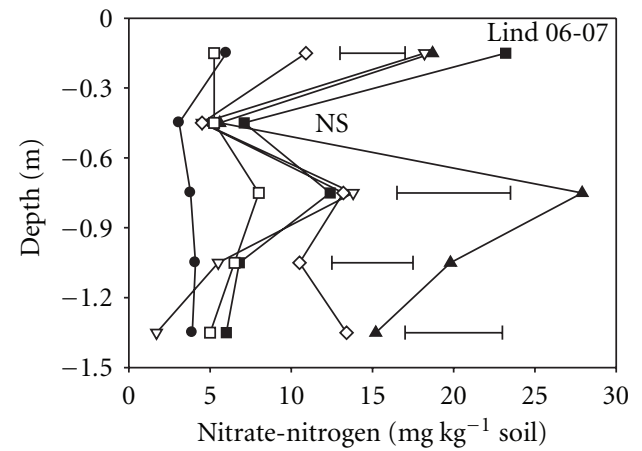

$\rightarrow 0 \mathrm{~kg} \mathrm{Nha}^{-1} \quad \checkmark$ 1x biosolids rate

$\rightarrow-56 \mathrm{~kg} \mathrm{~N} \mathrm{ha}^{-1} \quad-2 \mathrm{x}$ biosolids rate

$\neg 112 \mathrm{~kg} \mathrm{~N} \mathrm{ha}^{-1} \quad \square-$ Initial (fall 2006)

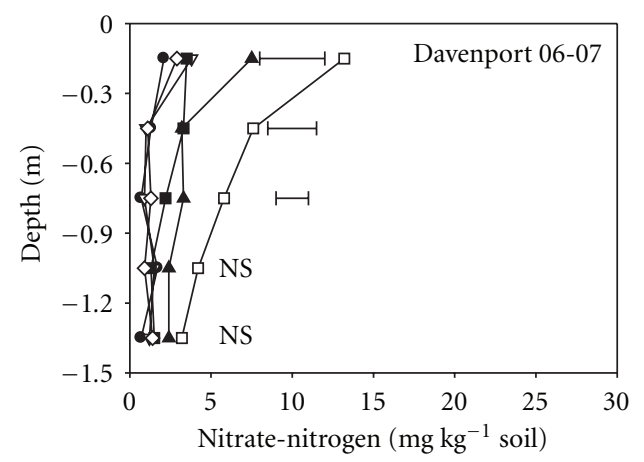

$\multimap 0 \mathrm{~kg} \mathrm{Nha}^{-1} \quad \checkmark 1 \mathrm{x}$ biosolids rate

$\rightarrow-56 \mathrm{~kg} \mathrm{~N} \mathrm{ha}^{-1} \quad-2 \mathrm{x}$ biosolids rate

$\rightarrow-112 \mathrm{~kg} \mathrm{~N} \mathrm{ha}^{-1} \quad-\square-$ Initial (fall 2006)

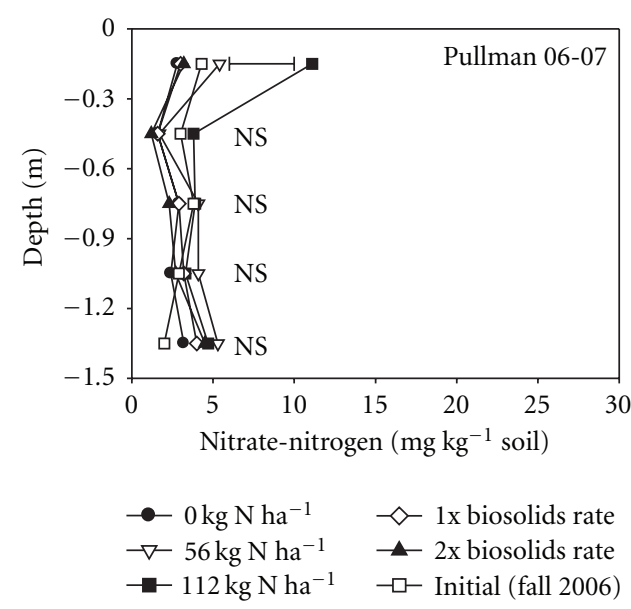

(a)

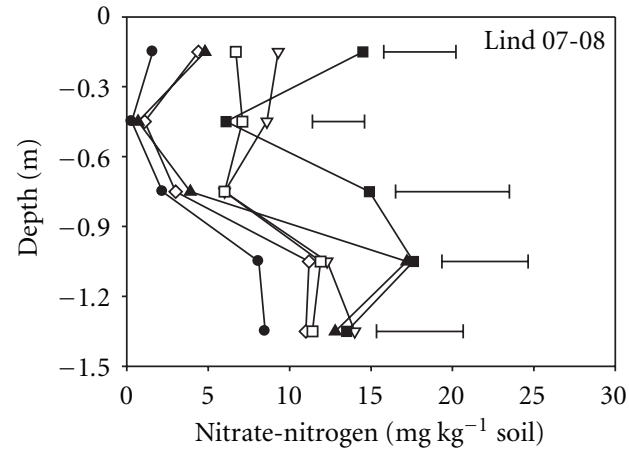

$-0 \mathrm{~kg} \mathrm{~N} \mathrm{ha}^{-1} \leadsto 1 \mathrm{x}$ biosolids rate

$\rightarrow-56 \mathrm{~kg} \mathrm{~N} \mathrm{ha}^{-1} \quad-2 \mathrm{x}$ biosolids rate

$\rightarrow 112 \mathrm{~kg} \mathrm{~N} \mathrm{ha}^{-1} \quad \square-$ Initial (fall 2007)

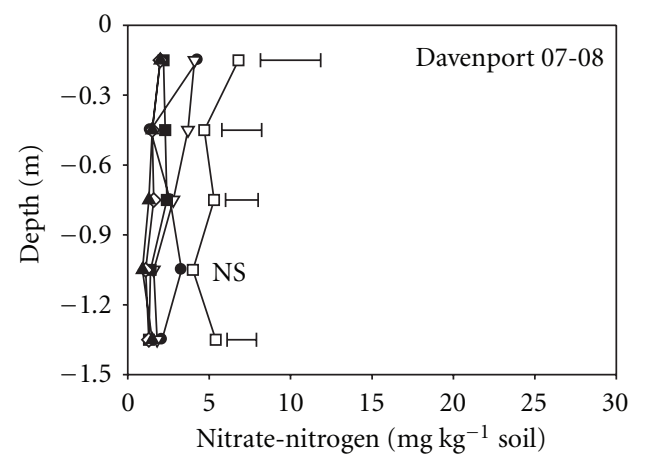

$\multimap 0 \mathrm{~kg} \mathrm{~N} \mathrm{ha}^{-1} \quad \checkmark-1 \mathrm{x}$ biosolids rate

$\rightarrow-56 \mathrm{~kg} \mathrm{~N} \mathrm{ha}^{-1} \rightarrow 2 \mathrm{x}$ biosolids rate

$\rightarrow 112 \mathrm{~kg} \mathrm{~N} \mathrm{ha}^{-1} \quad-\square-$ Initial (fall 2007)

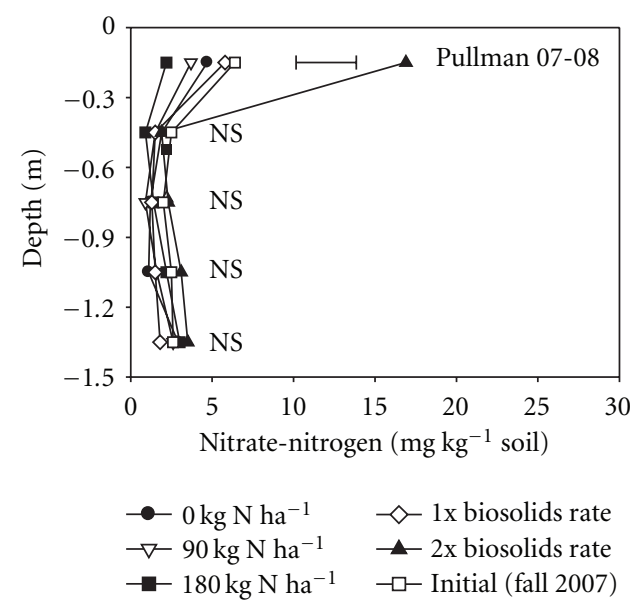

(b)

Figure 3: Postharvest soil profile $\mathrm{N}\left(\mathrm{NH}_{4}+\mathrm{NO}_{3}\right.$ for 0 to $0.3 \mathrm{~m}$ depth $+\mathrm{NO}_{3}$ only 0.3 to $1.5 \mathrm{~m}$ depth) for the hard red winter wheat treatments from the Lind, Davenport, and Pullman study locations in 2006-2007 (a) and 2007-2008 (b). Error bars represent Least Significant Difference (LSD) values at the $5 \%$ level. NS: no significant difference in $\mathrm{NO}_{3}-\mathrm{N}$ concentration among treatments for that sampling depth. Note that inorganic N rates were the same for all site-years except Pullman 2007-2008, where N rates were higher. This is reflected in the different legend for that panel.

$\mathrm{N}$ in the materials (Table 2). These availability indices were developed from studies in which biosolids were applied in the fallow period of a crop-fallow rotation and were incorporated with tillage $[3,18]$ or broadcast on the surface for a perennial forage crop [11]. In the present study, biosolids were applied shortly before planting and left on the surface. Both the timing of application relative to sowing and the absence of incorporation would contribute to lower N 

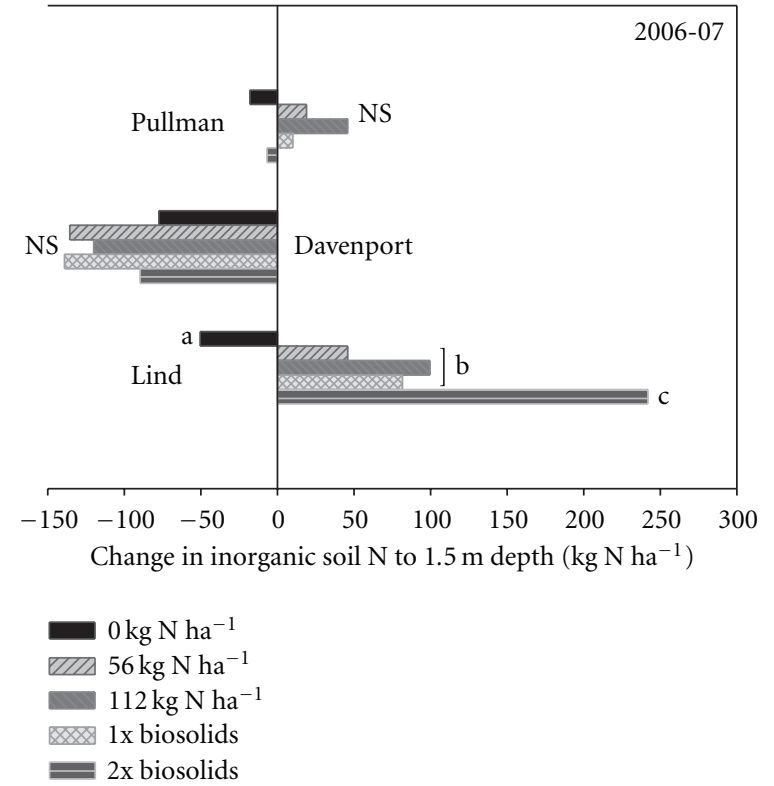

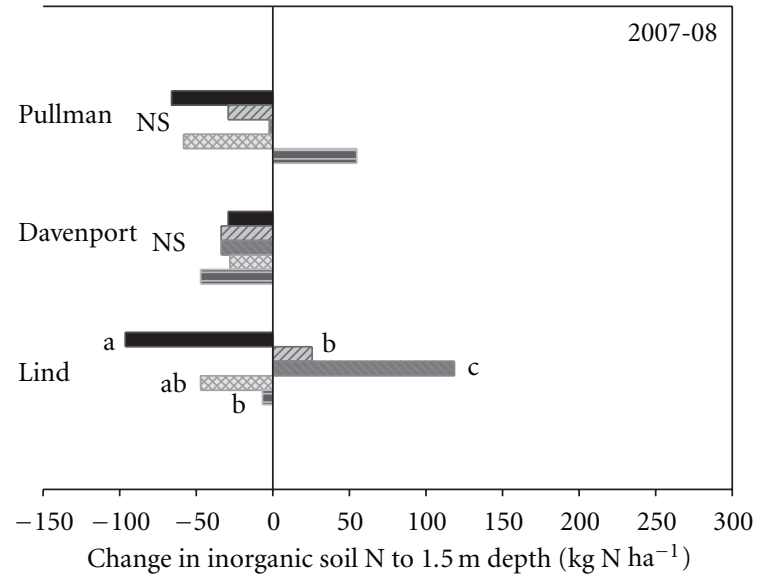

$0 \mathrm{~kg} \mathrm{~N} \mathrm{ha}^{-1}$

घI/ 56 (Lind/Davenport) or 80 (Pullman) $\mathrm{kg} \mathrm{N} \mathrm{ha}^{-1}$

112 (Lind/Davenport) or 160 (Pullman) $\mathrm{kg} \mathrm{N} \mathrm{ha}^{-1}$

$1 x$ biosolids

$2 \mathrm{x}$ biosolids

(a)

(b)

FIgure 4: Net changes in total inorganic soil $\mathrm{N}$ in a 1.5-m profile between the preplant (Table 1) and postharvest soil sampling of selected fertility treatments in hard red winter wheat at the Lind, Davenport, and Pullman study locations in 2006-07 (a) and 2007-08 (b). Values in the positive (right of vertical line) represent a net gain in soil profile inorganic $\mathrm{N}$ compared to the initial (preplant) sampling while values in the negative (left of the vertical line) represent a new depletion of soil profile N. Note the differences in inorganic $\mathrm{N}$ application rate between Lind/Davenport and Pullman in 2007-08.

availability to winter wheat than in previous studies [3]. Evidence from soil profile $\mathrm{N}$ measured postharvest (discussed later) also suggests that "Soundgro" biosolids $\mathrm{N}$ availability was overestimated in Table 2 calculations. Since the actual $\mathrm{N}$ available from biosolids is unknown and can only be estimated, we retained the statistical comparisons between $1 \times$ and $2 \times$ biosolids treatments and the intermediate and high fertilizer $\mathrm{N}$ rates (Figures 1 and 2). While the validity of this comparison could be argued, grain yields and grain protein concentrations with biosolids compared to fertilizer $\mathrm{N}$ were substantially higher and lower, respectively, across fertilizer $\mathrm{N}$ rates, and results of statistical comparisons would be similar regardless of the inorganic $\mathrm{N}$ rate selected for comparison to biosolids.

Grain yield responses to biosolids did not reflect a "haying off" effect observed with fertilizer N (discussed above). One explanation for this is that the rate of $\mathrm{N}$ mineralization from biosolids was not rapid enough to stimulate a flush of vegetative growth and lead to moisture depletion and stress. In fact, grain test weights of biosolids treatments were within acceptable ranges and did not indicate widespread stress. Also, higher yields from biosolids compared to fertilizer $\mathrm{N}$ were observed in 2008 when there was little indication of a negative yield response to high rates of fertilizer N. Previous studies comparing biosolids and fertilizer $\mathrm{N}$ responses in dryland areas of the PNW did not show consistently higher yields with biosolids materials [3]. A second explanation for the higher yields from biosolids in the present study is that other nutrients were deficient at these sites and were supplied in adequate quantities by the biosolids materials. At Lind and Davenport in 2007, soil test $\mathrm{P}$ was below critical levels while $\mathrm{S}$ was below critical levels for all site-years (Table 1). While some $\mathrm{P}$ and $\mathrm{S}$ was applied at as starter fertilizer with the seed at Davenport and Pullman, the rates were relatively low $\left(5 \mathrm{kgP}\right.$ and $\left.13 \mathrm{~kg} \mathrm{Sha}{ }^{-1}\right)$. The additional $\mathrm{P}$ and $\mathrm{S}$ associated with the biosolids may explain the higher yields associated with these treatments across site years.

In situations where grain yield was higher with biosolids than with comparable inorganic $\mathrm{N}$ treatments, grain protein content was often lower. This effect could be explained by the dilution of grain $\mathrm{N}$ in these higher yielding treatments, leading to lower grain protein. The inverse relationship between grain yield and grain protein concentration is a common phenomenon in wheat [15]. Another factor in this study may be the positional availability of $\mathrm{N}$ in the soil profile. Previous research has shown that high grain protein concentration is more easily achieved when $\mathrm{N}$ is available for uptake later in the season during grain filling $[16,17]$. In this dryland area where the soil surface dries rapidly, $\mathrm{N}$ located at depth in the profile where late-season moisture absorption occurs is more likely to contribute to high grain protein concentration. Central to the premise of this study is that biosolids are better suited to producing high protein hard red and white winter wheat than soft white winter wheat in these dryland environments, as was suggested earlier [3]. This does not appear to be the case under the conditions (time, placement) of biosolids application in this study. 
3.3. Soil Profile $N$ and $N$ Balance. Postharvest inorganic $N$ distributions for hard red winter wheat were variable among fertility treatments, particularly at Lind (Figure 3 ). Except for Lind and limited treatments at the 0 to $0.3-\mathrm{m}$ depth at Pullman, postharvest soil profile $\mathrm{N}$ was lower for inorganic and biosolids treatments than the initial soil profile $\mathrm{N}$. Interestingly, as evidenced by the higher amount of $\mathrm{NO}_{3}-\mathrm{N}$ at depth in the profile, there was some $\mathrm{N}$ movement to the 0.6 to $1.2-\mathrm{m}$ depth at the Lind location for the biosolids and high $\mathrm{N}$ rate treatments (Figure 3 ) even though this site received the least amount of precipitation and had some of the lowest preplant soil moisture (Table 1). The Lind site had significant preplant residual $\mathrm{N}$ in the profile (Table 1; Figure 3 ). This, coupled with relatively low yields and high $\mathrm{N}$ rates, resulted in some increase in soil $\mathrm{N}$ with intermediate and high $\mathrm{N}$ rate treatments. Regardless, as evidenced by the lack of statistical difference between treatments and the unfertilized control, there was little $\mathrm{N}$ movement below the $1.2 \mathrm{~m}$ depth in any treatment except at Lind.

When expressed as a net gain or loss of inorganic $\mathrm{N}$ from the profile, there was no difference in net $\mathrm{N}$ change in the soil profile among treatments at Davenport and Pullman, suggesting no greater risk of soil $\mathrm{NO}_{3}$ accumulation with biosolids than with inorganic fertilizer. There was a net increase in soil $\mathrm{N}$ for intermediate and high fertilizer rates and biosolids treatments at Lind in 2007 and for fertilizer treatments at Lind in 2008, compared to the unfertilized control. Accumulated $\mathrm{N}$ in the profile could be subject to leaching below the crop root zone in the fallow cycle at this location, particularly since much of this residual $\mathrm{N}$ is located at depth in the soil profile.

Overall, at the Davenport and Pullman sites, results indicate efficient use of residual and applied $\mathrm{N}$ forms regardless of the source (biosolids versus inorganic $\mathrm{N}$ ). While this is a promising finding, other studies in which high rates of biosolids were applied and/or applications were made in the fallow year, residual soil $\mathrm{N}$ increased, and there was some evidence of leaching loss $[3,8]$.

\section{Conclusions}

Biosolids applied within two weeks of planting and without incorporation were an efficient source of nutrients for dryland wheat production across a range of rainfall zones in eastern Washington. In situations of low to moderate preplant soil profile $\mathrm{N}$, organic $\mathrm{N}$ released by biosolids was well utilized by the crop with residual soil levels no greater than with inorganic $\mathrm{N}$ sources. Yields with biosolids were frequently higher than with inorganic $\mathrm{N}$ treatments, likely due to a combination of slow $\mathrm{N}$ release and contributions of other nutrients such as $\mathrm{P}$ and $\mathrm{S}$ that were deficient in these systems. When applied in this manner, biosolids were not effective at producing high grain protein concentrations in hard red or hard white winter wheat. If biosolids material was applied in the fallow year in low and intermediate precipitation zones, the impact on grain protein concentration may be greater. Early application of biosolids in the higher precipitation areas where annual cropping is practiced is not possible.

\section{Acknowledgments}

The authors would like to thank the Northwest Biosolids Management Association for financial support of this research. This research was supported by the Washington State University Agricultural Research Center under Hatch Project no. 0579.

\section{References}

[1] K. A. Barbarick, J. A. Ippolito, and D. G. Westfall, "Distribution and mineralization of biosolids nitrogen applied to dryland wheat," Journal of Environmental Quality, vol. 25, no. 4, pp. 796-801, 1996.

[2] C. G. Cogger, T. A. Forge, and G. H. Neilsen, "Biosolids recycling: nitrogen management and soil ecology," Canadian Journal of Soil Science, vol. 86, no. 4, pp. 613-620, 2006.

[3] D. M. Sullivan, A. I. Bary, C. G. Cogger, and T. E. Shearin, "Predicting biosolids application rates for dryland wheat across a range of Northwest climate zones," Communications in Soil Science and Plant Analysis, vol. 40, no. 11-12, pp. 17701789, 2009.

[4] K. A. Barbarick, J. A. Ippolito, and D. G. Westfall, "Biosolids effect on phosphorus, copper, zinc, nickel, and molybdenum concentrations in dryland wheat," Journal of Environmental Quality, vol. 24, no. 4, pp. 608-611, 1995.

[5] C. G. Cogger, D. M. Sullivan, A. I. Bary, and J. A. Kropf, "Matching plant-available nitrogen from biosolids with dryland wheat needs," Journal of Production Agriculture, vol. 11, no. 1, pp. 41-47, 1998.

[6] D. K. McCool, D. R. Huggins, K. E. Saxton, and A. C. Kennedy, "Factors affecting agricultural sustainability in the Pacific Northwest, USA: an overview," in Proceedings of the 10th International Soil Conservation Organization Meeting on Sustaining the Global Farm Symposium, D. E. Stott, R. H. Mohtar, and G.C. Steinhardt, Eds., pp. 255-260, Purdue University, May 1999.

[7] A. C. S. Rao, J. L. Smith, V. K. Jandhyala, R. I. Papendick, and J. F. Parr, "Cultivar and climatic effects on the protein content of soft white winter wheat," Agronomy Journal, vol. 85, no. 5, pp. 1023-1028, 1993.

[8] K. A. Barbarick, J. A. Ippolito, and J. McDaniel, "Fifteen years of wheat yield, $\mathrm{N}$ uptake, and soil nitrate- $\mathrm{N}$ dynamics in a biosolids-amended agroecosystem," Agriculture, Ecosystems and Environment, vol. 139, no. 1-2, pp. 116-120, 2010.

[9] R. Koenig, Eastern Washington Nutrient Management Guide: Dryland Winter Wheat, Washington State University Extension Bulletin, no. 1987, Washington State University Extension, Pullman, Wash, USA, 2005, http://cru.cahe.wsu.edu/CEPublications/EB1987/EB1987.pdf.

[10] J. T. Gilmour, C. G. Cogger, L. W. Jacobs, G. K. Evanylo, and D. M. Sullivan, "Decomposition and plant-available nitrogen in biosolids: laboratory studies, field studies, and computer simulation," Journal of Environmental Quality, vol. 32, no. 4, pp. 1498-1507, 2003.

[11] C. G. Cogger, A. I. Bary, and E. A. Myhre, "Estimating nitrogen availability of heat-dried biosolids," Applied and Environmental Soil Science. In press.

[12] S. O. Guy and R. M. Gareau, "Crop rotation, residue durability, and nitrogen fertilizer effects on winter wheat production," Journal of Production Agriculture, vol. 11, no. 4, pp. 457-461, 1998. 
[13] K. A. Barbarick and J. A. Ippolito, "Nutrient assessment of a dryland wheat agroecosystem after 12 years of biosolids applications," Agronomy Journal, vol. 99, no. 3, pp. 715-722, 2007.

[14] A. F. van Herwaarden, G. D. Farquhar, J. F. Angus, R. A. Richard, and G. N. Howe, "'Haying-off', the negative grain yield response of dryland wheat to nitrogen fertiliser. I. Biomass, grain yield, and water use," Australian Journal of Agricultural Research, vol. 49, no. 7, pp. 1067-1081, 1998.

[15] G. L. Terman, R. E. Ramig, A. F. Dreier, and R. A. Olson, "Yield-protein relationships in wheat grain as affected by nitrogen and water," Agronomy Journal, vol. 61, pp. 755-759, 1969.

[16] V. L. Cochran, R. L. Warner, and R. I. Papendick, "Effect of $\mathrm{N}$ depth and application rate on yield, protein content and quality of winter wheat," Agronomy Journal, vol. 70, pp. 964968, 1978.

[17] K. E. Sowers, B. C. Miller, and W. L. Pan, "Optimizing yield and grain protein in soft white winter wheat with split nitrogen applications," Agronomy Journal, vol. 86, no. 6, pp. 1020-1025, 1994.

[18] C. G. Cogger and D. M. Sullivan, Worksheet for Calculating Biosolids Application Rates in Agriculture, Pacific Northwest Extension Bulletin, no. 511, Washington State University Extension, Pullman, Wash, USA, 2007, http://cru.cahe.wsu .edu/CEPublications/pnw0511e/pnw0511e.pdf. 

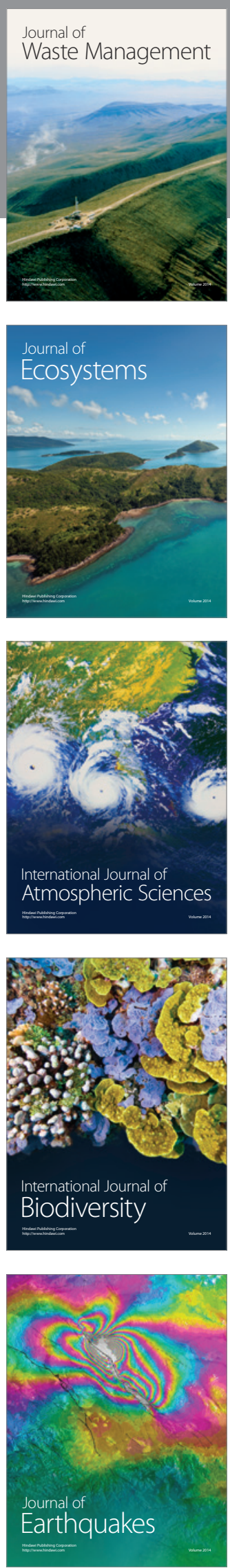
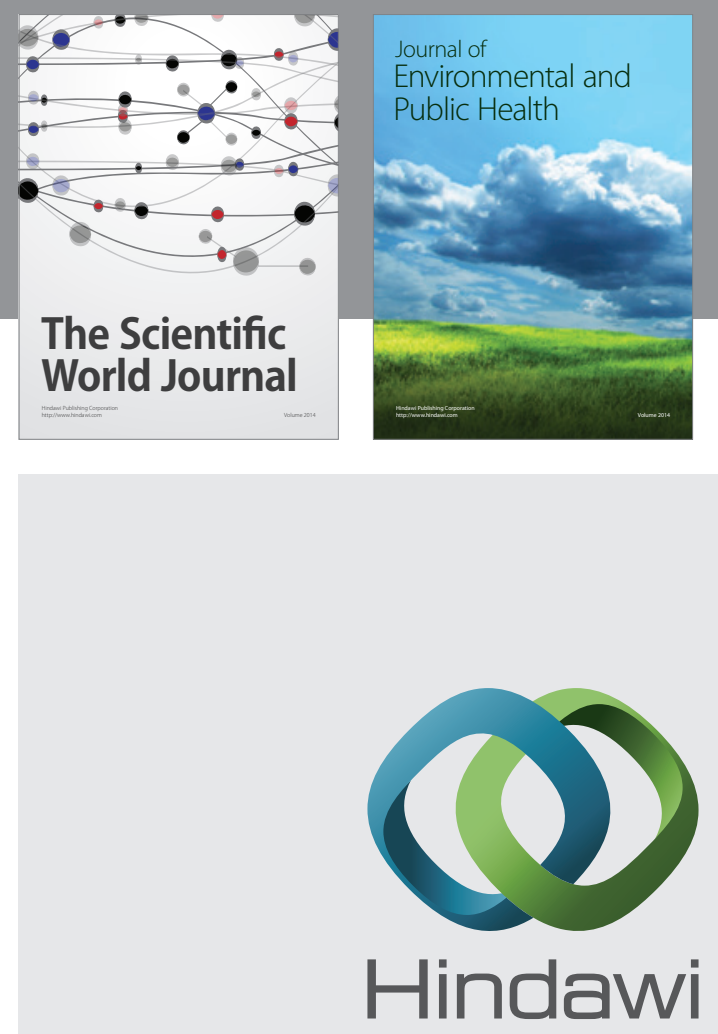

Submit your manuscripts at

http://www.hindawi.com
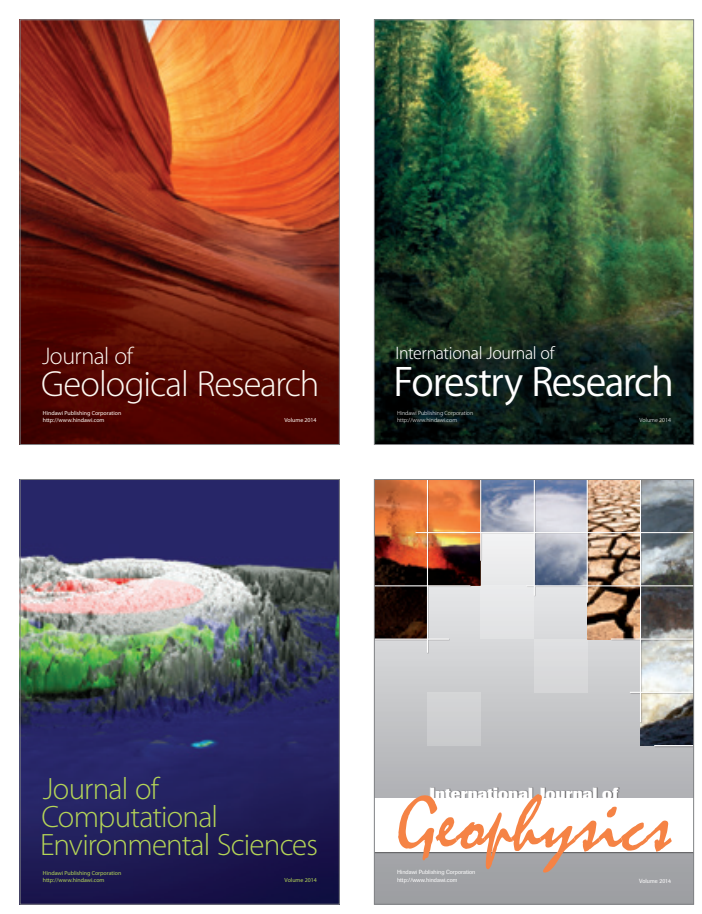
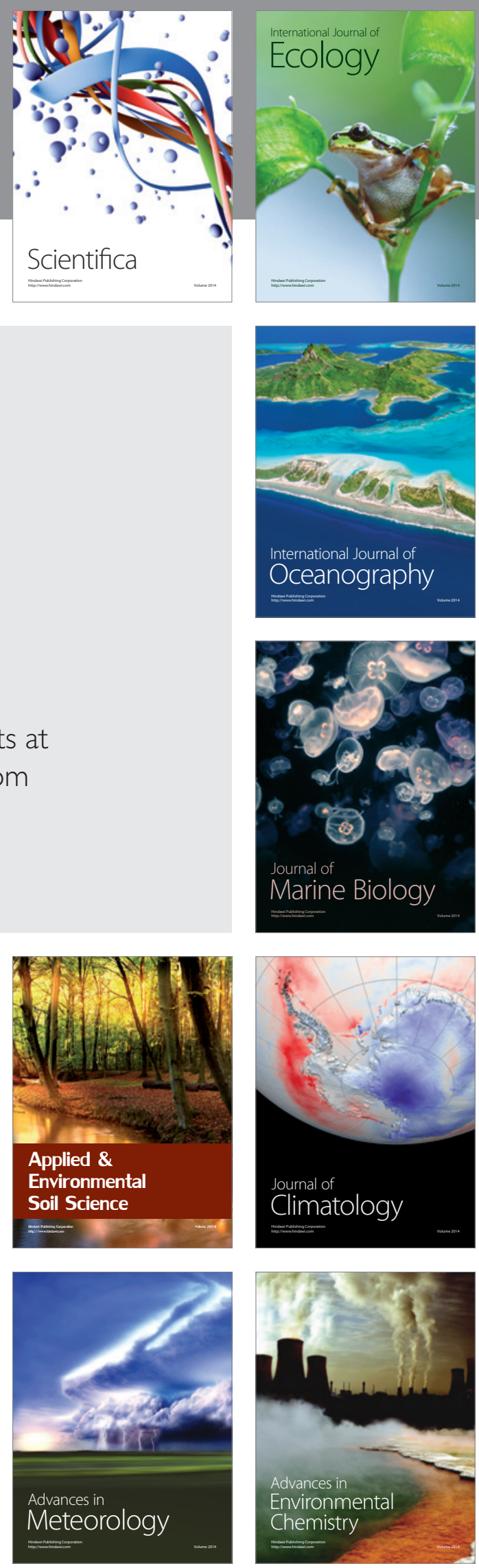